Barbara Maria Sageidet has a research focus on sustainability, science education, and inquiry learning in early childhood education. She is co-leader of a working package of the 'KINDknow - Centre for Systemic Research on Diversity and Sustainable Futures' at the Western Norway University of Applied Sciences, and leader of the research group 'Sustainability, STEM and Physical Education' at the Department of early childhood teacher education at the University of Stavanger. With a background in botany, ecology, paleoecology and soil sciences, and a PhD related to soil micromorphology, she has a special interest in interrelations at both local and global scales. Since 2010, she is an active member of the international research group 'Transnational Dialogues in Research in Early Childhood Education for Sustainability (TND)'.

\title{
'World Environmental Education Congresses' og naturfagenes rolle innen utdanning for bærekraftig utvikling
}

\begin{abstract}
This paper elucidates the role of the sciences within education for sustainable development as it is reflected on the World Environmental Education Congress (WEEC), a leading international conference since 2003. With a historical perspective, and observations, interviews and a look at the presentations of the WEEC 2015 and WEEC 2017, this study reveals an underrepresentation of science education, while a dominance was registered on WEEC conferences for ten years ago. Both the WEEC 2015 and WEEC 2017 provided plenty of information about science related realities, but little about how to get children and the youth to understand them. Only few of the papers and posters were addressed to children's and pupils learning related to physics or biogeochemical basic understanding. The understanding of natural interrelationships and concepts is essential for children and the youth for to become informed decision-makers and active participants in a sustainable society.
\end{abstract}

\section{INNLEDNING}

Naturfagundervisningen - internasjonalt 'science education'- har forandret sin rolle gjennom tidene, og forholdet til henholdsvis miljøundervisning eller 'environmental education' (EE), og utdanning for bærekraftig utvikling (ESD), har blitt diskutert siden 1960tallet (Breiting, 2011; Holbrook, 2009; Kopnina, 2012, 2014; Turmo \& Östergaard 2011; Öhman, 2006). Relativt ny i denne diskursen er FNs bærekraftsmål mot 2030 (UNESCO, 2015) som understreker at mange utfordringer i dagens samfunn er av teknologisk eller naturvitenskapelig karakter (cf. Scoullos, 2005; Sinnes \& Jegstad, 2011; Sundberg \& Ottander, 2014; Turmo \& Østergaard, 2011). I Norge er barnehagen samtidig blitt en offisiell del av den livslange læringen relatert til realfag (Kunnskapsdepartement, 2015). 
Artikkelen tar utgangspunkt i en historisk tilbakeblikk på miljøundervisningen og dens vei til utdanning for bærekraftig utvikling (ESD). Den biannuale 'World environmental education congress' (WEEC) er et møte for alle som arbeider med eller forsker relatert til miljøundervisning og bærekraftig utvikling på alle utdanningsnivåer. Den er en av de ledende internasjonale konferanser for utdanning for miljø og bærekraftig utvikling, og ses i denne sammenhengen på som en kontinuerlig og sentral arena der statusen og den utviklingen av 'science education' kan bli synlig (Breiting, 2009; Cutting \& Cook, 2009; Ferreira, 2013; Jickling, 2010). Artikkelen ser spesielt på WEEC i Gøteborg i 2015 (29. juni til 2. juli 2015), og på WEEC i Vancouver i 2017 (9.-15. september 2017). Ved hjelp av kvalitative innholdsanalyser vil studien belyse hvordan rollen av 'science education' innen utdanning for bærekraftig utvikling avspeiles på WEEC 2015 and 2017, og hvordan denne rollen kan utvikles videre, både med tanke på de 17 bærekraftmål (UNESCO, 2015) og inkludering av små barn i utdanningen.

\section{Metodologi}

Denne reflekterende studien er basert på en sosiokulturell tilnærming, som anser læring til å skje i sosiale kontekster (Lave \& Wenger, 1991) som for eksempel på konferanser, i barnehager og skoler. Med utgangspunkt i utviklingen fra miljøutdanning til utdanning for bærekraftig utvikling, skal det ses på rollen av naturfagundervisningen 'science education', slik den avspeiles på de to siste WEEC kongressene i 2015 og i 2017.

Disse to kongressene kan ses på som to case, og i denne eksplorerende refleksjonsstudien skal konferansene undersøkes ved hjelp av kvalitative innholdsanalyser av latent og manifest innhold (Neuendorf, 2017). Innholdsanalyser beskriver karakteristika, identifiserer sammenhenger, og fortolker et datamateriale, og kan bidra til en mer helhetlig forståelse (Neuendorf 2017, s. 42). I denne studien ble innholdet av de to konferansene analysert ved bruk av tilbakeblikk og intervjuer, fremstilt i form av fortellinger, i tillegg til programtemaer og en abstraktstikkordanalyse fra WEEC 15 (se avsnittene nedenfor). Følgende refleksjonsspørsmål skal belyses:

- Hvilken rolle spiller 'science education' på WEEC 2015 and 2017?

- Hvordan tematiserer konferansene 'science education' for (små) barn?

- Hvordan fremtrer undervisning og læring om grunnleggende naturfaglige konsepter på disse konferansene?

\section{Tilbakeblikk på konferansene og intervjuer}

Utgangspunkt for denne delen av innholdsanalysen er deltakende observasjon og intervjuer (som deler av en form for feltarbeide) på både WEEC 2015 og WEEC 2017, og et blikk på utvalgte foredrag og poster fra konferansene. På WEEC 2017, ble det tatt bilder av de fleste (58) poster i de observerte seksjonene, for å få et innblikk i posterbidragene og for å "kunne se tilbake" på deler av konferansen. På begge konferansene ble folk spontant spurt om å stille til åpne intervju, både deltakere, foredragsholdere og personer fra organisasjoner. Et titalls personer ble intervjuet på hver av konferansene, derav 2 og 6 navngitte personer henholdsvis på WEEC 2015 og WEEC 2017. Men ikke alle intervjuer bidrog med nye innholdselementer, og bare signifikante utsagn ble valgt ut for presentasjonen. Intervjuene belyser mer eller mindre 'latent' innhold av konferansen (Robson \& McCartan, 2016, s. 354; Neuendorf, 2017, s. 32). Potter og Levine-Donnerstein (1999) påpeker at det er en flytende overgang mellom manifest og latent innhold (Neuendorf, 2017, s. 163).

Deltakersituasjonen er en selektiv tilnærming, påvirket av forskerens/forfatterens for-forståelse, den kan ikke gi et heldekkende eller representativt bilde (Grønmo, 2004, s. 236, 373). Presentasjonene av de to konferansene fremhever tilsiktete innholdselementer og kan derfor ses som fortolkende fortellinger, eller narrativer (Bell, 2002; Chase, 2013), men er først og fremst refleksjoner. Ifølge Smith (2000) og Colucci-Gray, Perazzone, Dodman \& Camino (2013, s. 133) er narrativer egnet til å bidra til kvalitative innholdsanalyser.

I teorien av Colucci-Gray (et al., 2013) ble det identifisert fem kriterier, beskrevet under 'En teori for 'sustainability science'. Disse kriteriene ble brukt for å gjenkjenne og kategorisere meningsskapende 
innholdselementer fra refleksjonsstudiens samlete analysematerialet, og innholdselementene ble diskutert i forhold til refleksjonsspørsmålene (cf. Ryan \& Bernard, 2003). De fem kriteriene (ColucciGray et al., 2013) ble også valgt som overskrifter i diskusjons- og refleksjonsdelen.

\section{WEEC 2015 - kartlegging av foredragenes stikkord}

For å belyse naturfagenes rolle på konferansene, ble det i kjølvannet av WEEC 2015 kartlagt hvordan konferanseforedragene var fordelt på emner, basert på bidragsyternes stikkord i konferansen sin online abstraktdatabase. Tanken var å gjennomføre den samme kartleggingen også for WEEC 2017, men så langt har WEEC 2017 ikke publisert en tilsvarende abstraktdatabase. Kartleggingen i denne foreliggende publikasjonen skal være oppstarten av en planlagt longitudinell studie for å kunne sammenligne utviklingen på WEEC kongressene fremover med tanke på emnene som foredragene handler om.

Kartleggingen undersøker de fokus som deltakerne har hatt i sine presenterte foredrag. For foredragene på WEEC 2015 ble denne kartleggingen gjennomført ved hjelp av en kvalitativ begrepskategorisering av stikkordene (jf. Grønmo, 2004) til de 450 abstrakter, der hvert abstrakt hadde 3-4 stikkord. Det ble registrert hvor mange abstrakt som viser til de samme stikkord eller til stikkord som ligger innholdsmessig nært opp mot hverandre. Ved bruk av kvalitativ koding (Hjerm \& Lindgren, 2011) ble det identifisert nøkkelkategorier som peket seg ut (jf. Grønmo, 2004). Disse nøkkelkategoriene eller emner som samler stikkordene, er fremstilt i et søylediagram (Figur 1). Stikkord som mer eller mindre passet for alle eller veldig mange av abstraktene, som for eksempel "miljøundervisning”, er ikke tatt med i analysen.

\section{HISTORISK BAKGRUNN - MILøUTDANNING OG KONFERANSER}

Linken mellom kvalitet på miljøet og kvalitet på utdanningen ble til begrepet "environmental education", brukt av verdens første globale miljøorganisasjon "International Union for Conservation of Nature" i 1948 (Disinger, 1983; Palmer, 1998). Nødvendigheten av utdanning for miljøet og for bærekraftig utvikling trengte seg frem under den miljøpolitiske bevisstgjøringsprosessen på 1960 tallet, med blant annet boken "The silent spring" (Carson, 1962/2000). FNs første miljøkonferanse i Stockholm i 1972, ble fulgt av den Belgrader Charter (UNEP, 1975), med globale rammer for environmental education. FNs første konferanse for miljøutdanning var i Tbilisi, Sovjetunion i 1977 (UNEP, 1977). Brundtlandrapporten kom i 1987 (WCED, 1987), det fulgte Riokonferansen (UNEP, 1992). Etter en utdanningskonferanse i Thessaloniki i Hellas i 1997, fulgte den første WEEC kongress i Espinho, Portugal i 2003. For å bevare kontinuitet, og for å fremme debatt, praksis og forskning innen feltet, ble "WEEC - International Environmental Education Network" etablert. Siden møtet i Torino, Italia, i 2005, ble kongressen arrangert annet hvert år: Durban, South Africa (2007), Montréal, Canada (2009), Brisbane, Australia (2011), og Marrakech, Marokko i 2013 (http://www.environmentaleducation.org/en/who-we-are/the-weec-network.html).

Utdanning for miljøet har internasjonalt vært nært knyttet til biologi og økologiundervisning (Goldbech \& Jörgensen, 1990, s. 16, Sörlin \& Öckerman, 2002; Öhman, 2006). Med bakgrunn i Tbilisi deklarasjonen (UNEP, 1977) og oppfølgende konferanser, har miljøundervisningen i Norden hatt nøkkelord som livslang prosess, tverr- og flerfaglighet, metodemangfold, problemorientering, fokus på ute- og lokalmiljøet, det naturgitte og det menneskeskapte, og verdispørsmål (Goldbech \& Jörgensen, 1990, s. 15). Ifølge Breiting (2009) ble overgangen fra EE til ESD spesielt tydelig på WEEC 2007, både i 'tanker og praksis'. WEEC 2007 hadde omtrent like mye fokus på (den eldre) EE vinklingen, som på den utvidete og mer tverrfaglige ESD vinklingen, men var dominert av fagpersoner med miljøog naturfaglig bakgrunn. Etter hvert har mange forskere sett et skifte fra EE til ESD, der EE ble en del av ESD (Breiting, 2011; Eilam \& Trop 2010; Kopnina, 2012, 2014; Ärlemalm-Hagsér, 2013).

Etter en tid med debatt om hvor vidt læring rundt ESD kan være politisk objektiv med tanke på begrepet 'utvikling' (Garrard, 2007; Skulberg \& Harsvik, 2012), har FNs tiår for utdanning for 
bærekraftig utvikling (2005-2014) vært med på å etablere ESD internasjonalt, og utdypet innholdet av de fire dimensjoner naturmiljøet, den økonomiske, den sosiale og den politiske dimensjonen (UNESCO, 2005, 2012, 2014; Wals, 2009). Barn og unge, også i barnehagen, skal ikke bare lære i naturen og om naturen, men også for naturen (Rambøll, 2015; Ärlemalm-Hagsér, 2013).

UNESCO (2015) og de 17 bærekraftsmål mot 2030 understreker at menneskesamfunnet ikke lenger står i motsetning til naturen, men begge er deler av en helhet. Demokratisk deltakelse, rettferdighet mellom mennesker og folkeslag, helse og livskvalitet er sentrale fokus i dag, i tillegg til videreutvikling av handlingskompetanse for utvikling. De humanistiske fag og samfunnsvitenskaper er like viktige som naturfagene.

\section{EN TEORI FOR 'SUSTAINABILITY SCIENCE'}

Colucci-Gray (et al., 2013) introduserer en teori for 'sustainability science' basert på grunnleggende (naturfaglige) konsepter, epistemologiske og metodiske betraktninger. Teorien vil bidra til å orientere 'science education' mot en bærekraftig perspektiv. Forskergruppen påpeker at både naturvitenskap og naturfagundervisning har alltid vært påvirket av språk, kultur og samfunn, men historisk har deres fokus i stor grad vært på dypde analyser av utvalgte og avgrensete deler av virkeligheten. I nyere tid har naturfagbasert teknologi fått en enorm betydning for global energi-, material- og informasjonsflyt og for verdens mangfoldige naturlige, kulturelle og sosiale systemer. I disse komplekse systemene med mangfoldige nivåer, relasjoner og sammenhenger, forsvinner lett grensene mellom alle mulige prosesser og fenomener, og de er full av usikkerheter. På bakgrunn av denne bevisstheten at vi bare kan ha en ufullstendig forståelse av verden, foreslår Colucci-Gray (et al., 2013) inquiry baserte tverrfaglige undervisningsmetoder for å lære for situasjoner der fakta er usikre, verdiene er i konflikt, mye står på spill og raske avgjørelser er nødvendige (jf. Elmose \& Roth, 2005). Ved siden av verdsettelse, fremheves nødvendigheten av dialog og utveksling mellom alle mennesker fra barn til spesialistene, og det understrekes nødvendigheten av samtaler og samhandling mellom vitenskapen og utdanning. Utgangspunkt for metoden er de magfoldige relasjonene mellom og innenfor alle verdens komplekse og tverrfaglige systemer. Som utgangspunkt for en begynnende forståelse av disse systemene, vises til noen grunnleggende (naturfaglige) konsepter som kan brukes til å beskrive og forstå fenomener og prosesser i alle fagfelt, som for eksempel flyt ('flow'), barrierer ('boundaries') og utveksling ('exchange'), prosess og produkt, komponent og system, mikro og makro, eller kretsløp.

Både mellom to celler og mellom organismer og deres miljø, eller for eksempel mellom to barnehage, kan det være flyt av materialer, det kan være barrierer og det kan være utveksling i mangfoldige former. Konseptet 'kretsløp' kan beskrive ulike sammenhenger både i naturen og i samfunnet. Poenget er ikke å få (små) barn og unge til å forstå flest mulig konsepter så tidlig som mulig i livet, men hvis vi lykkes til gi dem en forståelse av et konsept, så innebærer dette et stor potensiale til forståelse for andre konsepter og til egne kreative konstruksjoner av tverrfaglig kunnskap (Colucci-Gray et al., 2013). Konseptenes forklaringer og kommunikasjon blir grunnlaget for 'links' mellom ulike andre konsepter, perspektiver og praktiske erfaringer i alle fag.

Sammenfattende fremhever teorien blant annet de følgende kriterier: tverrfaglighet og helheten, læring for krisemestring, dialog mellom vitenskapen og utdanning, grunnleggende (naturfaglige) konsepter, lokal og global tilnærming.

\section{ANALYSE AV INNHOLDSELEMENTER OG INNTRYKK FRA KONFERANSENE}

Etter et blikk på programtemaene fra WEEC 2015 og WEEC 2017, ble foredragsholdernes abstrakter på WEEC 2015 analysert, og deretter presenteres narrativer fra begge konferansene. 


\section{Temaer som ble satt opp for WEEC 2015 og WEEC 2017}

Kongressene WEEC 2015, med motto 'Planet and People - how can they develop together' og WEEC 2017, med motto 'Cultureducation - weaving new connections' (ordsammensetning av 'culture' og 'education'), inviterte til deltagelse med lignende temaer i programmene. Ny på WEEC 2017 var urbefolkningsperspektiver og etikk, se Tabell 1:

Tabell 1. Temaer fra programmene til WEEC 2015 og 2017.

\begin{tabular}{|c|c|}
\hline Programtemaer for WEEC 2015 & Programtemaer for WEEC 2017 \\
\hline 1. Taking children seriously in addressing global challenges & 1. Early Childhood Education \\
\hline 2. Sense of place in the digital age & 2. Place-based Education and local Outdoor Learning \\
\hline 3. Environmental Education and poverty reduction & 3. Architecture and Green Design \\
\hline 4. Learning for Green Cities & 4. Arts-based Approaches \\
\hline $\begin{array}{l}\text { 5. Concepts for environmental stewardship and sustain- } \\
\text { ability }\end{array}$ & 5. Agriculture and Garden-based Learning \\
\hline 6. Moving from awareness to action & 6. Global and Cultural Diversity \\
\hline $\begin{array}{l}\text { 7. Environmental and Sustainability Education and ac- } \\
\text { countability }\end{array}$ & 7. Urban Ecosystems \\
\hline $\begin{array}{l}\text { 8. Green Economy: education and learning for green jobs } \\
\text { in a green society }\end{array}$ & 8. Environmental Communication (and Uncertainty) \\
\hline 9. Research in Environmental and Sustainability Education & 9. Indigenous Knowledge \\
\hline 10. Educational policy development & 10. Ethics lead Learning and Sustainability \\
\hline \multirow{4}{*}{$\begin{array}{l}\text { 11. Education and learning for climate change adaptation } \\
\text { and resilience }\end{array}$} & 11. Social Responsibility and Agency/Activism \\
\hline & 12. Nature as Teacher/Nature as Researcher \\
\hline & 13. Global Policy and Environmental Education \\
\hline & $\begin{array}{l}\text { 14. Perspectives, Challenges and Innovation in Re- } \\
\text { search }\end{array}$ \\
\hline
\end{tabular}

\section{Foredragsholdernes emner på WEEC 2015 i Gøteborg}

Til en viss grad påvirker forutbestemte temaer hvem og hvilke bidrag som vil delta på en konferanse. Men forskerne og lærerne på sin side planlegger å presentere sin forskning eller sitt utviklingsarbeid på WEEC konferanser, også uavhengig av årets temaer. For å finne ut hva disse foredragene handler om, ble det gjennomført en kvalitativ begrepskategorisering av stikkordene til de 450 abstrakter for disse foredragene (jf. Grønmo, 2004).

Stikkordanalysen viste stor bredde og variasjon blant de muntlige foredrag. De til sammen 1419 registrerte stikkord fra alle abstraktene, viste 310 ulike stikkord som ble kategorisert inn under 34 emner som er fremstilt i Figur 1.

Topp emnet på WEEC 2015 viste seg å være 'bærekraftig livsstil', som var i fokus i hele 129 foredrag. Halvparten av foredragene hadde en generell fokus på undervisningspraksis og lærerutdanning på alle nivåer, noe som understrekes av de to nest hyppigste emner: 'didaktiske metoder' (117 foredrag) og 'skole, læreplaner og praksis' (107 foredrag) (Figur 1). Relativ sterkt representert var foredrag som omhandlet ulike former for samarbeid for bærekraftighet. Foredragene viste ellers mange eksempler på god praksis for miljø og bærekraftig utvikling. 


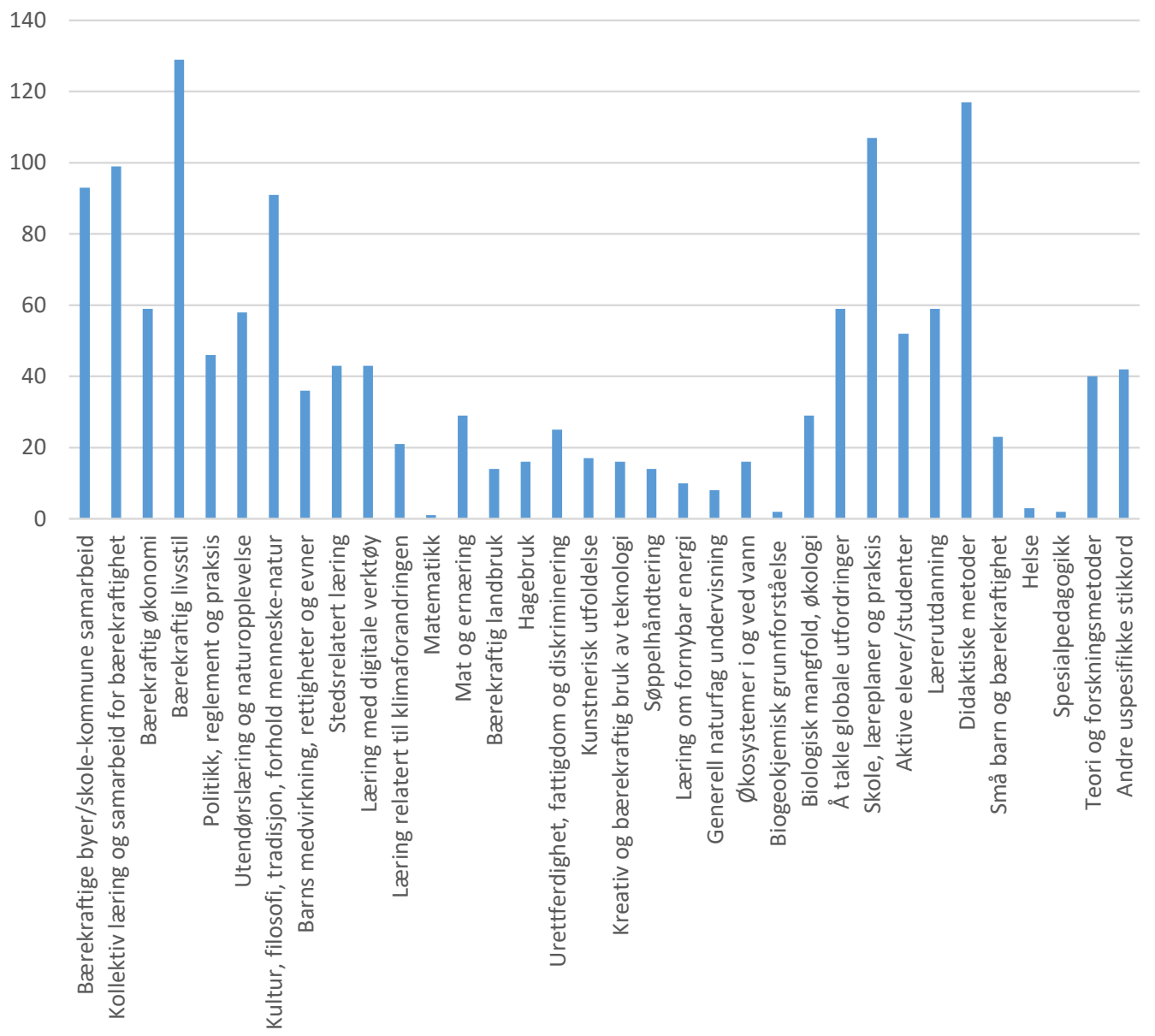

Figur 1. Lignende stikkord av alle konferanseforedrag på WEEC 2015, fordelt på emner. $(N=1419)$

\section{Narrativ fra WEEC 2015 i Gøteborg}

På åpningen av kongresssen understreket Co-chair Ingrid Pramling Samuelsen at utdanning for alle - alle land, alle gutter og jenter, alle aldre - er helt sentralt for global bærekraftighet, og er et mål som fortsatt ikke er nådd. Co-chair Arjen Wals påpekte det store globale bilde som blant annet viser fortløpende tap av biologisk mangfold og økosystemer, klimaproblematikken, forurensning av vann, luft, jord og organismer, fattigdom, sult, mangel på likestilling og tilgang til utdanning, krig og urettferdighet. Den italienske miljøsosiologen Mario Salomone henviste til Aichi-Nagoya Deklarasjonen (UNESCO, 2014), og påpekte spesielt betydningen av (læring om) naturvitenskap og teknologi for en bærekraftig utvikling.

Foredragene varierte fra organiserte førstehåndserfaringer om biodiversitet og jordfauna (Danielsson, Ekvall, Backman \& Carlson, 2015, Juni), til lav karbon konsepter og andre ideer for å redusere det økologiske fotavtrykket (Pradhan et al., 2015, Juli; UNEP, 2013). Foredraget til Ottander og Sundberg (2015, Juli) om muligheter og utfordringer for naturfaget til å bidra til arbeidet med bærekraftig utvikling i barnehagen, reiste en diskusjon rundt naturfaget, dets definisjon og relasjon til bærekraftig utvikling. I et intervju la miljøkjemikeren Michael Scoullos (Department of Chemistry, National and Kapodistirian University of Athens, Greece, pers. med. 02.07.15) merke til at mange foredragsholdere presenterte engasjert nye ord, nye begrep og nye modeller: 
"Men undervisningen blir ikke nødvendigvis bedre av det, barn kan bliforvirret, og også lærerne. Det er viktig at alle vet hva det snakkes om. Naturfag eller «sciences» bør bety det samme for alle som arbeider med det eller mener noe om det".

Betydningen av felles begrep ble også drøftet av Sadi Can Sönmez, en av ungdommene fra YRE (Young Reporters for the Environment), som skrev om kongressen i etterkant (Sönmez, 2015, Juli).

Ved kongressens avslutning i plenumet ble det understreket at det er handlinger, helst i felleskap, som vil smitte over, og at det er handlinger som lærerne skal fokusere på. En av konklusjonene var at samfunnet kan og bør stille krav til teknologien og vitenskap om å bidra med bærekraftige løsninger. På kongressen har teknologi og naturfag likevel vært litt i bakgrunnen. Dette inntrykket bekreftes under en siste intervju med en av konferansedeltakere, PhD student Anna Lehtonen fra Finland (pers. med. 02.07.15). Hun var storfornøyd med konferansen, men var skeptisk hvor vid det kan komme bærekraftige løsninger fra naturfag og teknologi. Hun bekreftet inntrykket at mange på kongressen ikke oppfattet naturfag og teknologi helt som del av det samme bærekraftige felleskapet.

\section{Narrativ fra WEEC 2017 i Vancouver}

På åpningen påpekte key note speaker Charles Hopkins (UNESCO Chair in Reorienting Teacher Education to Address Sustainability) at informasjon om miljø og klima er blitt lett tilgjengelig, troverdig, og pålitelig, men utfordrer oss når det gjelder hvordan utdanningen skal være. Ifølge Hopkins er det viktig å ha fokus på både miljøvern og en god, solid og bærekraftig økonomi, men han understreker,

"We cannot continue to consume as much as we do today, we need more sharing"..."environmental education is critical and has to try to raise a new focus on the skills needed for green jobs and sustainable lifestyles,...”.

Han etterlyste også ideer for utdanning for bærekraftig utvikling. Professor Julie Davis fra QUT (Queensland University of Technology, pers. med. 10.09.17), Brisbane, Australia, understreket Hopkins syn i intervjuet:

"I feel we have not come much further than at the Tbilisi Declaration, I feel a little depressed... but here is much energy on this conference!"

Davis likte at barnehagefeltet var mye sterkere representert enn på tidligere WEECs.

Key note speaker Dr. Jeanette Armstrong (Canadian Research Chair in Okanagan Indigenous Knowledge and Philosophy) snakket om læring og utdanning i hennes kultur, Okanagan (Syilx) urbefolkningen. Hos Okanaganerne er det å være et menneske nært knyttet til kunnskap om ulike livssyklus og deres helhetlige sammenheng i naturen, og et krav om å være del av denne helheten og verne om den. Urbefolkningens syn på bærekraftighet innebærer innsikten i det som er nødvendig å vite for å overleve. Denne respekten for og verdsettelsen av kunnskap kan bli for utydelig innenfor dagens 'utdanning for bærekraftig utvikling', der den holistiske forståelsen er sterkere assosiert med sosiale aspekter enn med naturfaglig kunnskap. Okanagan folket har et spesielt forhold til steder. Et sted er under stadig forandring. Som mennesket må vi tilpasse oss til stedet vårt, og også til planeten vår. Ifølge perspektivet til denne urbefolkningen, så er læring og kunnskap det mest essensielle for å overleve,

«...you need to know! Otherwise, you cannot survive!"

Kunnskap handler om forståelse av sammenhenger og konsekvenser, og naturen innebærer også etiske prinsipper.

Hovedformen for presentasjonene på hele konferansen var poster som ble utstilt tidsavgrenset under parallele gruppeøkter i ulike rom. De varierte poster utstillingene viste blant annet studier om lokale miljøtiltak som integrerer barn og unge, stedbasert, og online læring. Små barn kan for eksempel lære i felleskap med ungdommer (Lador, 2017). 
Professor Wade Davis, key note speaker på den andre konferansedagen, fremhevet at alle kulturer er et svar på spørsmålet hvem vi er og hvilke etiske verdier vi har. Også Elizabeth May (leder av Green Party of Canada), snakket om verdier på den fjerde konferansedagen. Hun fremhevet dokumentene 'The earth charter' (Corcoran, 2004) og 'Laudato Si - On care of our common home' (Pope Francis, 2015) som viktige universale statements som understreker:

"We are in a climate emergency!» and "Human development is primarily of being more, not having more".

May spurte hva som skal til for å oppnå forandring, og etterlyste en grunnleggende forandring av måten vi tenker utdanning på, og fremhevet: «We need to be different people!».

I intervjuet om hennes personlige inntrykk når det gjelder de sterkest representerte emnene på konferansen, svarte Savannah Steinhilber (School Program Leader, Biogeoscience Institute, Kananaskis, University of Calgary, Canada, pers. med. 12.09.17), at dette var det generelle fokus på miljøvern og kulturelt eller personlig tilknytning til et sted. Posterne som hun hadde sett tematiserte mest hvordan å engasjere barn og unge i bærekraftige tiltak. Steinhilber som selv viste en poster om utfordringene for naturfaglærere ved å undervise om klimaproblematikken (Poirier Hollander, 2017, September), fremhevet at hun synes det er vanskelig å se et skille mellom kultur, naturvitenskap ('science') og realfagsundervisning, men at både naturvitenskap og utdanning er deler av de kulturelle relasjoner til et sted eller land. Professor Julie Davis så en sterk sosialvitenskapelig orientering på konferansen, og konferansens co-organisator dr. David Zandvliet (Simon Fraser University, Canada, e-post med. 03.11.17) understrek betydningen av urbefolkningenes bidrag til bærekraftig utvikling. For Zandvliet bør 'science' plasseres ved siden av andre epistemologiske rammer, slik at vi får en holistisk tilnærming. Under den avsluttende plenumsdiskusjonen ble det spurt hvor mange av deltakerne som kom fra 'science' eller 'science education', og det viste seg at dette gjald nesten en fjerde del av alle i salen.

\section{DISKUSJON OG REFLEKSJONER}

\section{Hvilken rolle spiller 'science education' på WEEC 2015 og 2017?}

Del av den tverrfaglige helheten

Globalt felleskap og lokalt samarbeid for mer bærekraftighet var et hovedbudskap på både WEEC 2015 og WEEC 2017. Dette var i tråd med det fokuset som også FNs tiår for bærekraftig utvikling (2005-2014) hadde satt (UNESCO, 2005, 2012, 2014; Wals, 2009). De fire dimensjonene kom frem med sitt mangfold. Mens tidligere forskning har påpekt en overvekt av læring om naturen (Engdahl \& Ärlemalm-Hagsér, 2014), så har den økologiske dimensjonen nå blitt en integrert del i en stor variasjon av fler- og tverrfaglige sammenheng. Figur 1 viser at det økologirelaterte emnet 'utendørslæring og naturopplevelse' var like sterkt representert som emnet 'bærekraftig økonomi' på WEEC 2015 . 'Stedsrelatert læring' var et fokus som samlet omtrent en tiendedel av alle foredrag på WEEC 2015 (Figur 1), og var det andre prioritets tema i programmet for WEEC 2017 (Tabell 1).

Programmene til begge kongressene viste stor (tverr)faglig variasjon og bredde. Spesielt WEEC 2015 var tydelig inspirert av de 17 bærekraftsmål (UNESCO, 2030), med temaer som reduksjon av fattigdom (bærekraftsmål 1 og 2), grønne byer og økonomi (bærekraftsmålene 8, 9 og 11), og en sterk fokus på utdanning (bærekraftsmål 4), og også på globale (klima)utfordringene. WEEC 2017 valgte grønn design (bærekraftsmål 9 og 11), diversity, ethics and social responsibility (bærekraftsmål 1,2, $5,10,12,16)$, urban ecosystems (bærekraftsmål 11 og 15). Hagelæring var et naturfaglig emne på begge kongressene (Tabell 1).

\section{Læring for krisemestring}

Armstrong sitt key note foredrag på WEEC 2017, kom med et interessant og, ifølge Hopkins og Davis, etterlyst impuls som belyste det store overlapp mellom urbefolkningskunnskap og naturfaglig kunnskap, og at begge utfyller hverandre. Ifølge Colucci-Gray (et al., 2013, s. 136) blir denne relasjonen 
spesielt tydelig med tanke på urbefolkningers styrke på lokalkunnskap, mens det er et overvekt på naturfaglig (og digital) informasjon i mer overordnete og globale målestav. Selv om WEEC 2015 foredragene ikke hadde fokus på relasjonen mellom urbefolkningskunnskap og naturfaglig kunnskap, så ble denne relasjonen antydet i konferansens kopling mellom 'læring med digitale verktøy' og 'stedsrelatert læring' (to omtrent like sterkt representerte emner, se Figur 1), gjennom programtemaet 'sense of place in the digital age' (Tabell 1). Interessant for skolebarn var digitale spill om økologiske konsekvenser av miljøskadelige tiltak og handlinger (Borrelle, Frielick \& Leuzinger, 2015, Juni) og om artskunnskap (Robinson \& Robinson, 2015, Juni). Disse kan understøtte læring for å takle krisesituasjoner.

\section{Hvordan tematiserer konferansene 'science education' for (små) barn? Dialog mellom vitenskap og utdanning}

Begge konferansene tok opp barn som første tema i programmet. WEEC 2015 sine ord "Taking children seriously...", inviterte til dialog mellom vitenskap og utdanning (Colucci-Grey et al., 2013), mens WEEC 2017 satt fokus på små barn (Tabell 1). Blant de likevel relativ få presentasjoner på begge konferansene som omhandlet 'små barn og bærekraftighet', handlet de fleste om hvordan barn og unge kan bli medaktører og beslutningstakere.

\section{(Naturfaglige) konsepter}

Mange foredrag omhandlet hvordan holdninger og (forbruker)adferd kan endres for å redusere vårt økologiske fotavtrykk. Bare enkelte foredrag handlet om barnas oppfatninger og forståelser rundt miljø og klimaforandringsproblematikken (Almeida \& Brady, 2015, Juni), eller om barnehage barns artskunnskap og holdninger til dyr (De Niz Robles, Crispin, Ruiz Perez \& Hernandez, 2017, September), eller om deres kunnskap om økosystemet (Okjong, 2017, September).

\section{Hvordan fremtrer undervisning og læring om grunnleggende naturfaglige konsepter på disse konferansene?}

Så vid det var overskuelig, så ble en begynnende forståelse av blant annet fornybar energi eller læring relatert til klimaforandring, lite tematisert innen barnehagefeltet, selv om det etterlyses større variasjon og flere perspektiver for små barns læring om bærekraftig utvikling (Ärlemalm-Hagsér \& Sundberg, 2016).

Flere bidrag på begge konferansene hadde fokus på lærernes basiskompetanser. I tråd med mange tidligere referanser har Scoullos påpekt viktigheten av basiskompetanser for naturfaglæringen på alle utdanningsnivåer, også i barnehagen (Hjelmseth Hagen, 2013; Kallery \& Psillos, 2001; Rambøll, 2015; Ottander og Sundberg, 2015, Juli; jf. Jensen \& Sølberg, 2012; Kunnskapsdepartement, 2012; Scoullos \& Malotidi, 2004; Sönmez, 2015, Juli). Figur 1 viser tydelig (med lave score for relaterte emner) at naturfaglig grunnforståelse har inntatt en marginal rolle på WEEC 2015. Det kunne blant annet forventes at flere av abstraktene som omhandlet 'bærekraftig livsstil' (det emnet som var hyppigst i fokus, se Figur 1), skulle også omhandle naturfaglig grunnforståelse, men dette er bare tilfelle for en liten del av dem. Vi har ikke informasjon til sammenligning fra WEEC 2017. Key note speakerne Salomone (WEEC 2015) og Armstrong (WEEC 2017) fremhevet den spesielle betydningen av naturfagene for verden vi lever i. I tverrfaglige sammenheng var biologifaget relativ godt representert på begge konferansene, på WEEC 2015 gjennom 'utendørslæring og naturopplevelse', og på WEEC 2017 gjennom tallrike utendørs-, hage- og stedrelaterte prosjekter. Likevel var det relativ få foredrag som konkret omhandlet barn og unges læring av (de relaterte) naturfaglige konsepter (Figur 1) (jf. Colucci-Gray et al., 2013).

\section{Lokal og global tilnarming}

Flere emner med sentrale relasjoner til FNs bærekraftsmål (UNESCO, 2015) var besjedent representert på WEEC 2015 (Figur 1), som for eksempel 'mat og ernæring'(bærekraftsmål 1, 2, 3), 'hagebruk' og 'bærekraftig landbruk'(bærekraftsmål 2, 12, 15), 'biologisk mangfold og økologi'(bærekraftsmål 13, 14, 15), 'økosystemer i og ved vann'(bærekraftsmål 6, 14), 'læring relatert til klimaforandringene' 
(bærekraftsmål 13, 14, 15), 'kreativ og bærekraftig bruk av teknologi' (bærekraftsmål 7, 9, 11, 12, 13), 'søppelhåndtering' (bærekraftsmål 6, 11, 12, 14, 15), og 'læring om fornybar energi' (7, 9, 11, 12, 13, 14, 15). Svært lite i fokus var 'helse' (bærekraftsmål 3), og bare et foredrag handlet om hvordan elever kan få en 'biogeokjemisk grunnforståelse' av de globale miljøutfordringer (bærekraftsmål 4, 6, 7, 11, 12, 13, 14, 15) (Koutalidi \& Scoullos, 2015, Juni). Fra WEEC 2017 var det ikke mulig å få en så detaljert oversikt, men heller ikke der var de 17 bærekraftmål eller grunnleggende naturfaglige konsepter spesielt i fokus. Både på WEEC 2015 og WEEC 2017 var foredragene som omhandlet 'læring om fornybar energi' i hovedsak rettet mot behovet, bevissthet og bygningsdesign, men lite om formidling av de bakomliggene naturfaglige konsepter.

\section{SAMMENFATTENDE REFLEKSJON}

\section{Hvorfor og hvordan bør 'science education' utvikles videre, for å fremme naturfaglig arbeid med (små) barn og for å støtte opp om de 17 bærekraftsmål?}

Når UNESCO (2015) har som mål å fremme utdanningen (bærekraftsmål 4), så er det ikke minst fordi det er - mer enn noen ganger før - en sammenheng mellom kvaliteten på utdanningen globalt og kvaliteten på miljøet. FNs bærekraftsmål mot 2030 (UNESCO, 2015) gir naturfagene, teknologien og 'science education' en viktig oppgave til å viderutvikle undervisningen, slik at barn og unge kan forstå verden og sin egen rolle i den. Det er viktig at naturfag stadig oppdaterer og fornyer sin viktige rolle, og at barn og unge blir bevisste den mangesidige betydningen som naturfag har for samfunnet (Bergem, Goodchild, Henriksen, Kolstø, Nortvedt \& Reikerås, 2014; Rambøll, 2015) og ikke minst for bærekraftig utvikling (UNESCO, 2015).

Den Nordiske strategien for bærekraftig utvikling (Nordiska ministerrådet, 2013, s. 31) og Norges realfagsatsning frem til 2019 (Kunnskapsdepartement, 2015) inkluderer alle nivåer i utdanningen. Samtidig har både den norske læreplanen i naturfag (Kunnskapsdepartementet, 2013), og den norske Rammeplanen for barnehagen (Kunnskapsdepartement, 2017) satt spesielt fokus på bærekraftig utvikling. Disse føringene ønsker at de unge skal få en utdanning som gir dem etter hvert oppdaterte kompetanser som skal støtte opp om bærekraftig utvikling og fremover om de 17 bærekraftsmål (UNESCO, 2015).

Overgangen fra EE til ESD medførte en breiere forståelse av mangfoldige tverrfaglige aspekter, relatert til kultur, samfunn og politikk, og en styrking av de lærendes handlingskraft, kritisk tenkning og selvstendig 'citizenship' (cf. UNESCO 2012). Men etter at 'science education' mistet dominansen i 2007 (Breiting, 2009), viser den besjedne andelen av foredrag med spesifikk naturfaglige fokus i denne studien (Tabell 1), at fagområdet var nokså svak representert på WEEC 2015, der miljøkjemikeren Scoullos påpekte at

"mange foredrag ga informasjon om naturvitenskapelige realiteter, men få omhandlet hvordan vi kan få barn og unge til å forstå dem".

Noe lignende gjelder for WEEC 2017. På begge konferansene ser 'science education' ut til å ha inntatt en mindre synlig og mindre konkret rolle innenfor den ellers svært positive utviklingen til mer tverrfagligheten, noe som også flere andre informanter bekreftet.

Kopnina (2012, 2014) ser en nedtoning av den økologiske pilaren innen ESD. Hun medgir at miljøproblemer først og fremst er sosiale problemer, in den forstand at årsakene og mulige løsninger er i hovedsak antropogene og kan tas tak i innenfor samfunnet. Men Kopnina advarer mot en overskygging av det økosentriske perspektiv, d.v.s. vern av naturmiljøet for sin egen del (jf. Næss, 1976). Kopnina (2014) konstaterer at overgangen fra EE til EDS har medført en bevegelse vekk fra en tidligere økosentrisk fokus til en sterkere antroposentrisk fokus, og hun argumenterer for en ny iakttagelse av den Belgrader Charter (UNEP, 1975) som understreker blant annet behovet for naturfaglige kunnskaper og ferdigheter. 
Selv om 'science' kan ses på som en av mange epistemologiske rammer, så er så å si alle miljøargumenter basert på naturvitenskapelig kunnskap (Carson, 1962/2000, Yearley, 2014). Viten om ozonlaget, global oppvarming, artsmangfoldet, solpanel og isotopanalyse er basert på naturvitenskapelig og teknologisk forskning. En forståelse av disse sammenhengene blir mer og mer utfordrende og komplisert, både for eksperter, for (barnehage)lærere og for små barn. Men Colucci-Gray (et al., 2013) påpeker at nettopp en fokus på slik forståelse kan bidra til å fremme barn og unges kreativitet.

Ikke bare Charles Hopkins og Savannah Steinhilber stiller spørsmålet hvordan (barnehage)lærere kan arbeide med disse komplekse, og delvis vanskelige naturfag- og bærekraftrelaterte emner (jf. Qualter, 1996, s. 22 f). Det er viktig å gi barn og unge motivasjon for utforsking i både den tverrfaglige bredden og også den mer konkrete naturfaglige dybden, og det er viktig å formidle at tilegnelse av realfaglig kunnskap blir verdsatt. Det danske Science-kommune-prosjektet (2008-2011, Jensen \& Sølberg, 2012) og den norske realfagsatsing (2015-2019; Bergem et al., 2014; Kunnskapsdepartementet, 2015; Rambøll, 2015) hadde eller har blant annet som mål å forbedre barn og unges kompetanse i realfag ved systematisk og helhetlig arbeid med faget fra barnehage til fullført grunnskole.

På WEEC 2017 understreket Armstrong at kunnskap og spesielt naturfaglig kunnskap har alltid vært helt nødvendig for å overleve. Urbefolkningsbarn har lært om økologien i nærmiljøet, om livssyklus og sammenhenger i naturen. Armstrong fikk frem at urbefolkninger faktisk har en veldig sterk fokus på naturfaglig kunnskap som den mest essentielle delen av den holistiske tenkningen (jf. Næss, 1976). Colucci-Gray (et al., 2013) påpeker at vitenskapelige fokus ofte er på det globale nivået, mens urbefolkninger har sine fokus på lokalt nivå. Barnehagen har i denne sammenhengen også sin styrke i sitt fokus på nær- og lokalmiljøet, der barn for eksempel kan observere artsmangfold.

Barn har til alle tider lært ved perifer deltakelse i felleskapet (Lave \& Wenger, 1991, Rogoff, Mistry, Göncü, Mosier, Chavajay \& Heath, 1993). Det har alltid vært en utfordring å videreformidle det som er nødvendig å vite for å (over)leve fra generasjon til generasjon (jf. Corcoran, 2004), og spesielt det som de voksne selv var usikre på eller ikke visste. Verdens mangfoldige prosesser og fenomener er full av usikkerheter, også for eksperter og forskere (Colucci-Gray et al., 2013). Usikkerhetene viser seg blant annet ved bruk og deling av naturressursene, ulikhet og urettferdighet, og enhver form for sosiale konflikter i verden (González-Gaudiano \& Gutiérrez-Pérez, 2017), og også i relasjon til en sunn livsstil (Norddahl, Einardottir \& Oskarsdottir, 2017), og barn er internasjonalt den mest sårbare gruppen i denne sammenheng. På WEEC 2017 var usikkerhet et programtema (Tabell 1), og May snakket i sitt key note foredrag om at verden er i en akutt nødsituasjon. Å forholde seg til usikkerheter og risiko, er blant nøkkelkompetansene for bærekraftig utvikling (UNESCO, 2017, s. 10), og for å nå de 17 bærekraftmål. I arbeidet med (små) barn, trenger ikke usikkerhet å være noe negativt. Læring for eksempel ute i naturen eller gjennom naturfaglige eksperimenter kan by på mangfoldige uforutsigbarheter som kan inspirere barna til utforskning og kreativitet og kan gi dem en begynnende forståelse for at de aktiv kan medvirke og påvirke fremtiden (jf. Colucci-Gray et al., 2013).

Spesielt for barnehagelærere er det blitt en større utfordring å hjelpe barna til å få en begynnende forståelse av naturfaglige og teknologiske sammenhenger i dagliglivet i dag, enn det var bare for noen tiår siden. Vind- og vannhjul for eksempel har vært vanlig å arbeide med i barnehagen. Men hvordan skal vi prøve å gi barnehagebarn en begynnende forståelse av solpanel når vi ikke selv helt forstår hvordan de virker?

En (begynnende) innføring i grunnleggende naturfaglige konsepter på alle utdanningsnivåer kan understøttes av en integrert dialog med eksperter (Colucci-Gray et al., 2013). Med sine helheltlige og tverrfaglige arbeidsmåter har barnehagen den beste forutsetning blant alle utdanningsnivåer for å videreutvikle tverrfaglig 'science education' for bærekraftig utvikling. Barnehagen er kjent med inquiry-basert læring (Sageidet, 2012), men ifølge Colucci-Gray (et al., 2013) er det viktig å vise barna veldig konkret, hvilke begrep eller konsepter som er i fokus, og utvikle sammen med dem hvordan en kan tilnærme seg dette begrepet eller konseptet, enten beskrivende, funksjonell, gjennom fagover- 
kripende sammenhenger, i tidsperspektiv og/eller ved kreativ transformasjon (Colucci-Gray et al., 2013). Slike inquiry-prosesser kan være både spennende, kreative og lærerike for barna, og inspirere dem til metakognitiv tenkning (jf. Pramling Samuelsson \& Asplund Carlsson, 2003) og til medvirkning. For eksempel kan vi hjelpe barna å se nøye på detaljer og samtidig skaffe seg oversikt ved å relatere til større sammenheng og helheter. Nøkkelord og begrep i disse sammenheng vil stimulere barnas språkutvikling og er også didaktisk betydningsfulle for hvordan innholdet og budskapet formidles. Det er også svært viktig med verdsettelse av hvert enkelt barns deltakelse, uttrykksmåter og bidrag, og med inkluderende etiske holdninger (jf. Sageidet, 2012). (Barnehage)lærere bør våge å bruke tid sammen med barna på bærekraftig utvikling generelt og spesielt på forståelsen av sammenhenger, (biogeokjemiske) kretsløp, prosesser og konsepter i naturen og hvordan mennesker påvirker dem. Noen barn og unge kan også bli inspirert til å velge naturfag og teknologi som deres fremtidige bidrag til å forbedre verden (jf. Rohaan, Taconis \& Jochems, 2008; Turmo \& Østergaard, 2011).

\section{KONKLUSJON}

Studien gir et innblikk i hvordan 'science education' og relaterte emner har vært representert på WEEC 2015 og WEEC 2017, som viste til et inspirerende mangfold av forskning, tiltak og strategier for å videreutvikle utdanning for bærekraftig utvikling. Med utgangspunkt i kriteriene til ColucciGray, viser studien at 'science education' har orientert seg mot bærekraftighet på disse to konferansene, ved en utvikling i retning tverrfaglighet, lokale og globale tilnærminger, og dialog mellom vitenskapen og utdanningen. Å gi (små) barn og unge en begynnende forståelse av naturfaglige konsepter, var likevel nokså lite i fokus på begge konferansene, og dette gjaldt også læring relatert til fysikk eller biogeokjemiske kretsløp, selv om naturfagene og teknologi har fătt en økt betydning for å nå FNs bærekraftsmål.

Ved å sette fokus på usikkerhet og urbefolkningsperspekiver, har WEEC 2017 fremhevet behovet for å finne nye veier mot mer bærekraftighet. Innenfor en holistisk og mer økosentrisk orientering, kan dagens naturfagundervisning hente inspirasjon fra urbefolkningers strategier til å mestre kriser og til å overleve, og fra deres verdtsettelse av naturfaglig kunnskap. Naturfagundervisningen kan videreutvikles til å støtte opp om FNs bærekraftsmål ved å introdusere barn helt fra barnehagealderen - gjerne i dialog med eksperter - til (enkle) grunnleggende naturfaglige konsepter som barn etter hvert kan bruke kreativ til å forstå fenomener, prosesser og sammenheng i alle fagfelt, og til å bli informerte beslutningstakere og aktive deltakere i et bærekraftig samfunn.

\section{TAKK}

Tusen takk til professor Michael Scoullos (University of Athens), PhD student Anna Lehtonen (University of Hensinki), professor Julie M. Davis (Queensland University of Technology), Dr. David Zandvliet (Simon Fraser University), Savannah Steinhilber (University of Calgary), Dr. Jo-Anne Ferreira (Southern Cross University), Yoshiyuki Nagata (University of the Sacred Heart, Tokyo) og Megan McGinty (University of Washington) for intervjuene. Takk til de anonyme reviewer og til professor Ellen Karoline Henriksen (Universitetet i Oslo) og professor Eva Ärlemalm-Hagsér (Mälardalens Høgskola). Studien ble finansiert av Universitetet i Stavanger.

\section{REFERANSER}

Almeida, S.C. \& Brady, C. (2015, Juni). Children's Perceptions of Climate Change, and Their Sense of Environmental Empowerment. Paper at the World Environmental Education Congress WEEC 2015, Gøteborg, http://weec2015.org/

Bell, J.S. (2002). Narrative Inquiry: More than just telling stories. TESOL Quarterly 36(2), 207-213. doi: $10.2307 / 3588331$ 
Bergem, O.K., Goodchild, S., Henriksen, E.K., Kolstø, S.D., Nortvedt, G.A. \& Reikerås, E. (2014). Realfag - relevante, engasjerende, attraktive, lærerike. Rapport fra ekspertgruppa for realfagene. Oslo: Kunnskapsdepartement.

Borrelle, S., Frielick, S. \& Leuzinger, S. (2015, Juni). The Global Change app: Engaging learners through the creative transformation of research. Paper at the World Environmental Education Congress WEEC 2015, Gøteborg, http://weec2015.org/

Breiting, S. (2009). Issues for environmental education and ESD research development: looking ahead from WEEC 2007 in Durban. Environmental Education Research 15(2), 199-207. doi: $10.1080 / 13504620902807584$

Breiting, S. (2011). Et paradigmeskift for miljøundervisning - på vej mod Uddannelse for Bæredygdig Udvikling. In K. Kragh Blume Dahl, J. Læssøe \& V. Simovska (Eds.) Essays om dannelse, didaktik og handlekompetanse - inspirert af Karsten Schnack (pp. 93-104). Institutt for Didaktik, Danmarks Pædagogiske Universitetsskole, Århus Universitet.

Carson, R.L. (1962/2000). Silent spring. (new edition). Modern Classics, London: Penguin Books.

Chase, S.E. (2013). Narrative inquiry: still a field in the making. Chapter 2. In N.K. Denzin \& Y.S. Lincoln (Eds.) Collecting and Interpreting Qualitative Materials (pp. 55-83). Forth Edition. SAGE publications.

Colucci-Gray, L., Perazzone, A. Dodman, M. \& Camino, E. (2013). Science education for sustainability, epistemological reflections and educational practices: from natural scienes to trans-disciplinarity. Cultural Studies of Science Education, 8, 127-183. doi: 10.1007/s11422-012-9405-3

Corcoran, P. Blaze (2004). What if? Educational Possibilities of the Earth Charter. Educational Studies, 36(1), 108-117. doi: 10.1207/s15326993es3601_9

Cutting, R. \& Cook, R. (2009). The World Environmental Education Congress 2007: a critical appraisal. Environmental Education Research, 15(2), 177-187. doi: 10.1080/13504620802578491

Danielsson, K., Ekvall, H., Backman, L. \& Carlson, M. (2015, Juni). Hands-on experience with the bugs that make the soil we stand on and live off. Paper at the World Environmental Education Congress WEEC 2015, Gøteborg, http://weec2015.org/

De Niz Robles, M. \& Crispin, A.F. \& Hernández, N.A. (2017, September). Drawings as a methodological tool to evaluate knowledge and attitudes towards animals in kindergarten children. Poster at the World Environmental Education Congress WEEC 2017, Vancouver, http://weec2017. eco-learning.org/, University of Madrid.

Disinger, J. (1984). Environmental Education Research News. The Environmentalist, 1984(4), 109112. doi: 10.1016/So251-1088(84)92375-1

Eilam, E. \& Trop, T. (2010). ESD pedagogy: A guide for the perplexed. The Journal of Environmental Education, 42(1), 43-64. doi: 10.1080/00958961003674665

Elmose, S. \& Roth, W.M. 2005. Allgemeinbildung. Readiness for living in a risk society. Jounal of Curriculum Studies, 37(1), 11-34. doi: 10.1080/0022027041000229413

Engdahl, I. \& Ärlemalm-Hagsér, E. (2014). Education for sustainability in swedish preschools. Chapter 13. In J.M. Davis \& S. Elliott (Eds.) Research in Early Childhood Education for Sustainability (pp. 112-124). New York: Routledge.

Ferreira, J.-A. (2013). $6^{\text {th }}$ World Environmental Education Congress, Brisbane, Australia. Journal of Education for Sustainable development, 7(2), 143-147. doi: 10.1177/0973408214526483

Garrard, G. (2007). Ecocritisism and education for sustainability. Pedagogy, 7, 359-383.

Goldbech, O. \& Jörgensen, F. (1990). Miljöundervisning i Norden: - en utredning. Nordic Council of Ministers, $72 \mathrm{p}$.

González-Gaudiano, E.J. \& Gutiérrez-Pérez, J. (2017). Resilient Education: Confronting perplexity and uncertainty. In B. Jickling \& S. Sterling (Eds.) Post-Sustainability and Environmental Education (pp. 125-138). Palgrave Studies in Education and the Environment. Springer International Publishing AG. doi: 10.1007/978-3-319-51322-5_9 
Grønmo, S. (2004). Samfunnsvitenskapelige metoder. Fagbokforlaget. 452 p.

Hjelmseth Hagen, M. (2013). Lærerkompetanse og elevpresentasjoner. Sammenhenger mellom lærerens faglige kompetanse i realfag og elevenes prestasjoner i naturefag. Masteroppgave i profesjonsrettet naturfag. Høgskolen i Nesna, http://brage.bibsys.no/xmlui/bitstream/handle/11250/275585/1/Master_Hagen_2013.pdf

Hjerm, M. \& Lindgren, S. (2011). Introduksjon til samfunnsvitenskapelig analyse. Oslo: Gyldendal Akademisk, $149 \mathrm{p}$.

Holbrook, J. (2009). Meeting challenges to sustainable development through science and technology education. Science Education International, 20(1/2), 44-59.

Jensen, A. \& Sølberg, J. (2012). Hvad kan vi lære af Science-kommune-prosjektet? MONA, 2012(1), 66-83.

Jickling, B. (2010). Reflecting on the $5^{\text {th }}$ World Environmental Education Congress, Montreal, 2009. Journal of Education for Sustainable Development, 4(1), 25-36. doi: 10.1177/097340820900400110

Kallery, M. \& Psillos, D. (2001). Preschool teachers content knowledge in science: their understanding of elementary science concepts and of issues raised by children's questions. International Journal of Early Years Education, 9(3), 165-179. doi: 10.1080/09669760120086929

Kopnina, H. (2012). Education for sustainable development (ESD): the turn away from 'environment' in environmental education? Environmental Education Research, 18(5), 699-717. doi: $10.1080 / 13504622.2012 .658028$

Kopnina, H. (2014). Revisiting education for sustainable development (ESD): Examining Antropocentric bias through the transition of environmetal education to ESD. Sustainable development, 22, 73-83. doi: 10.1002/sd.529

Koutalidi, S. \& Scoullos, M. (2015, Juni). Designing didactic material for better understanding of bio-geochemical cycles and their connections with global Environmental and Sustainable Development issues. Paper on the World Environmental Education Congress WEEC 2015, Gøteborg, http://weec2015.org/

Kunnskapsdepartementet (2012). Kunnskap for en felles fremtid. Revidert strategi for utdanning for bærekraftig utvikling (2012-2015), Utdanningsdirektoratet 2012, http://www.regjeringen. no/upload/KD/Vedlegg/UH/Rapporter_og_planer/Strategi_for_UBU.pdf

Kunnskapsdepartementet (2013). Læreplan i naturfag. Oslo: Utdanningsdirektoratet, http://data. udir.no/klo6/NAT1-03.pdf

Kunnskapsdepartementet (2015). Tett på realfag. Nasjonal strategi for realfag i barnehagen og grunnopplæringen (2015-2019). https://www.regjeringen.no/no/dokumenter/tett-pa-realfag/ id2435042/

Kunnskapsdepartement (2017). Rammeplan for barnehagen - innhold og oppgaver. Oslo: Utdanningsdirektoratet.

Lador, I. (2017, September). "It's in their nature" - Teenagers and toddlers interacting in a Forest kindergarten in Israel. Poster at the World Environmental Education Congress WEEC 2017, Vancouver, http://weec2017.eco-learning.org/

Lave, J., \& Wenger, E. (1991). Situated learning: Legitimate peripheral participation. Cambridge, England: Cambridge University Press, 138 p.

Neuendorf, K.A. (2017). The content analysis guide book. 2. Edition. SAGE publication, Inc., 437 p. Næss, A. (1976). Økologi, samfunn og livstil. Oslo: Universitetsforlaget.

Norddahl, K., Einarsdottir, J. \& Oskarsdottir, G. (2017). Early Childhood Teachers' (Pre- and Compulsory School Teachers) Use of the Outdoor Environment in Children's Learning about Living Beings. In T. Waller, E. Ärlemalm-Hagsér, E.B.H. Sandseter, L. Lee-Hammond, K. Lekies \& S. Wyver (Eds.) The Sage Handbook of Outdoor Play and Learing (pp. 594-608). SAGE publications Ltd.

Nordiska ministerrådet (2013). Ett gott liv i ett hållbart Norden - Nordisk strategi för hållbar utveckling. København: Nordiska ministerrådet, 34 p., www.norden.org 
Okjong, Ji (2017, September). Understanding young children's ecosystem interconnectedness through 'the living things in the park' project. Poster at the World Environmental Education Congress WEEC 2017, Vancouver, http://weec2017.eco-learning.org/, Korea National University of Transportation.

Ottander, C. \& Sundberg, B. (2015, Juli). Possibilities and obstacles for science as a foundation for education for sustainability in preschools. Paper at the World Environmental Education Congress WEEC 2015, Gøteborg, http://weec2015.org/

Palmer, J. (1998). Theory of Environmental Education. Routledge, 298 p. doi: $10.1080 / 13504620701581539$

Poirier Hollander, S. (2017, September). Toolkit for Teaching climate change”, poster at the World Environmental Education Congress WEEC 2017 in Vancouver, http://weec2017.eco-learning. org/, Biogeoschience Institute, University of Calgary, Canada.

Pope Francis (2015). Laudato Si - On care of our common home. Encyclical letter. Roma: Vatican Press. http://w2.vatican.va/content/francesco/en/encyclicals/documents/papa-francesco_20150524_enciclica-laudato-si.html

Pradhan, M., Omrcen, E., Holmberg, J., van't Land, H. (2015, Juli). Sustainable campuses: Universities walking the talk. Symposium abstract on the World Environmental Education Congress WEEC 2015, Gøteborg, http://weec2015.org

Pramling Samuelsson, I. \& Asplund Carlsson, M. (2003). Det lekande lärande barnet i en utvecklingspedagogisk teori. Stockholm: Liber.

Potter, W.J. \& Levine-Donnerstein, D. (1999) Rethinking validity and reliability in content analysis, 27:3, 258-284. doi: 10.1080/o0909889909365539

Qualter, A. (1996). Differentiated primary science. Exploring primary science and technology. London: Open University Press. 192 p.

Rambøll (2015). Kunnskapsgrunnlaget - realfag i barnehagen. Oslo: Rambøll management, 41 p.

Robinson, M. \& Robinson, A. (2015, Juni). Mobile Games and Biodiversity Conservation. Paper at the World Environmental Education Congress WEEC 2015, Gøteborg, http://weec2015.org/

Robson, C. \& McCartan, K. (2016). Real World Research. John Wiley and Sons, Inc, 560 p.

Rogoff, B. Mistry, J., Göncü, A., Mosier, C., Chavajay, P. \& Heath, B. (1993). Guided participation in cultural activity by toddlers and caregivers. Monographs of the Society for Research in Child Development, 58(8), 1-179.

Rohaan, E.J., Taconis, R. \& Jochems, W.M.G. (2008). Reviewing the relations between teachers' knowledge and pupils' attitude in the field of primary technology education. Int $\mathrm{J}$ Technology Des Educ (open access doi: 10.1007/s10798-008-9055-7).

Ryan, G.W. \& Bernard, H. R. (2003). Data management and analysis methods. In N.K. Denzin \& Y.S. Lincoln (Eds), Collecting and interpreting qualitative materials. Sage publications.

Sageidet, B.M. (2012). Inquiry baserte naturfagaktiviteter i barnehagen. In T. Vist \& M. Alvestad (Eds.) Læringskulturer i barnehagen - flerfaglige forskningsperspektiver (pp. 115-139). Oslo: Cappelen Damm Akademisk.

Scoullos, M. \& Malotidi, V. (2004). Handbook on methods used in Environmental Education and Education for Sustainability Development. MIO-ECSDE, Athens, 2004.

Scoullos, M. (2005). 3rd World Environmental Education Congress, "Environmental Education: from where to where?” Conference Procedings.

Sinnes, A.T. \& Jegstad, K.M. (2011). Utdanning for bærekraftig utvikling: To unge realfagslæreres møte med skolehverdagen. Norsk Pedagogisk tidsskrift, 95, 248-259.

Skulberg, H. \& Harsvik, T. (2012). Utdanning for bærekraftig utvikling. Temanotat 2/2012. Seksjon for samfunnsspørsmål, utredninger og internasjonale saker. Oslo: Utdanningsforbundet.

Smith, C.P. (2000). Content analysis and narrative analysis. In T. Rei \& C. Judd (Eds.), Handbook of research methods in social and personality psychology. Cambridge University Press.

Sönmez, S.C. (2015) Sustaining Further: What's After Sustainability? YRE (Young Reporters for the Environment) report article from the WEEC 2015, http://weec2015.org/press-area/reports-from-youth/ 
Sörlin, S. \& Öckerman, A. (2002). Jorden en ö: en global miljöhistoria. ( $2^{\text {nd }}$ edition) Stockholm: Natur och kultur, $240 \mathrm{p}$.

Sundberg, B. \& Ottander, C. (2014). Science in preschool - a foundation for education for sustainability? A view from Swedisch preschool teacher education. Chapter 17. In J.M. Davis \& S. Elliott (Eds.) Research in Early Childhood Education for Sustainability (pp. 280-293). Routledge.

Turmo, A. \& Østergaard, E. (2011). Levende realfag! Norsk Pedagogisk Tidsskrift, 2011(4), 245-246.

UNEP (1975). The Belgrader Charter. Adopted by the UNESCO-UNEP International Environmental Workshop, October 13-22, 1975. http://portal.unesco.org/education/en/file_download.php/ 47f146a292do47189d9b3ea7651a2b98The+Belgrade+Charter.pdf

UNEP (1977). Tbilisi declaration. Intergovernmental conference on environment education in Tbilisi, Georgia (USSR), October -14-26, 1977, organized by the United Nations Education, Scientific, and Cultural Organization (UNESCO) in cooperation with the U.N. Environment Programme (UNEP). http://www.gdrc.org/uem/ee/tbilisi.html

UNEP (1992). Agenda 21. United Nations Environment Programme. http://www.unep.org/Documents.Multilingual/Default.asp?documentid $=52$

UNESCO (2005). Decade of Education for Sustainable Development 2005-2014. Draft International Implementation Scheme. Paris: UNESCO.

UNESCO (2012). Shaping the education of tomorrow. Paris: UNESCO, 89 p.

UNESCO (2014). Aichi-Nagoya Declaration on Education for Sustainable Development. World Conference Aichi-Nagoya (Japan), 10-12 November 2014, http://www.unesco.org/new/fileadmin/ MULTIMEDIA/HQ/ERI/pdf/Aichi-Nagoya_Declaration_EN.pdf

UNESCO (2015). Transforming our world: the 2030 Agenda for Sustainable Development. Paris: UNESCO.

UNESCO (2017). Education for sustainable development goals - Learning objectives. Paris: UNESCO. http://unesdoc.unesco.org/images/o024/o02474/247444e.pdf

Wals, A. (2009). United Nations decade of education for sustainable development (DESD, 20052014) Review of contexts and structures for education for sustainable development 2009. UNESCO Learning for a sustainable world. UNESCO, Paris.

WCED (1987). Our Common Future. A report from the United Nations World Comission on Environment and Development. Oxfort University Press.

Yearley, S. (2014). The green case. A sociology of environmental issues, arguments and politics. 1. Edition, 1991. London: Routledge. 208 p.

Ärlemalm-Hagsér, E. (2013). Lärande för hållbar utveckling i förskolan. Kunskapsinnehåll, delaktighet och aktörskap kommunicerat i text. Nordisk barnehageforskning, 5(14), 1-17.

Ärlemalm-Hagsér, E. \& Sundberg, B. (2016). Naturmöten og källsortering - En kvantitativ studie om lärende för hållbar utveckling i förskolan. NorDiNa, 2016(2), 140-156. doi: 10.5617/nordina.1107

Öhman, J. (2006). Pluralism and criticism in environmental and sustainable education. Envrionmental Education Research, 12(2), 149-63. doi: 10.1080/13504620600688856 